\title{
Mijn hart stond van stocht bijna stil! (F. Harmsen van Beek) : dichters en hun biografen
}

Citation for published version (APA):

Meijer, M. J. H. (2014). Mijn hart stond van stocht bijna stil! (F. Harmsen van Beek) : dichters en hun biografen. Maastricht University. https://doi.org/10.26481/spe.20140613mm

Document status and date:

Published: $13 / 06 / 2014$

DOI:

10.26481/spe.20140613mm

Document Version:

Publisher's PDF, also known as Version of record

\section{Please check the document version of this publication:}

- A submitted manuscript is the version of the article upon submission and before peer-review. There can be important differences between the submitted version and the official published version of record.

People interested in the research are advised to contact the author for the final version of the publication, or visit the DOI to the publisher's website.

- The final author version and the galley proof are versions of the publication after peer review.

- The final published version features the final layout of the paper including the volume, issue and page numbers.

Link to publication

\footnotetext{
General rights rights.

- You may freely distribute the URL identifying the publication in the public portal. please follow below link for the End User Agreement:

www.umlib.nl/taverne-license

Take down policy

If you believe that this document breaches copyright please contact us at:

repository@maastrichtuniversity.nl

providing details and we will investigate your claim.
}

Copyright and moral rights for the publications made accessible in the public portal are retained by the authors and/or other copyright owners and it is a condition of accessing publications that users recognise and abide by the legal requirements associated with these

- Users may download and print one copy of any publication from the public portal for the purpose of private study or research.

- You may not further distribute the material or use it for any profit-making activity or commercial gain

If the publication is distributed under the terms of Article $25 \mathrm{fa}$ of the Dutch Copyright Act, indicated by the "Taverne" license above, 


\section{Maastricht University}

Prof. Dr M.J.H. (Maaike) Meijer

'M'n hart stond van stocht bijna stil!' (F. Harmsen van Beek).

Dichters en hun biografen 


\title{
'M'n hart stond van stocht bijna stil !' (F. Harmsen van Beek).
}

\author{
Dichters en hun biografen
}


'M'n hart stond van stocht bijna stil !'

Foto omslag: portret van F. Harmsen van Beek midden jaren zestig. Screenshot door J. Kircz van een hergebruikt fragment uit (hoogstwaarschijnlijk) de tv-uitzending van KRO Galerij 25-10-1965. De originele uitzending is verloren gegaan.

CBS 10471 Design \& print: Canon Business Services, Maastricht

\section{Dichters en hun biografen}

Universiteit Maastricht

Faculteit Cultuur-en Maatschappijwetenschappen

Centrum voor Gender en Diversiteit

Postbus 616

6200 MD Maastricht

Tel: 043-3882669

Email.m.meijer@maastrichtuniversity

Email secretariaat: r.wennek@maastrichtuniversity.nl

\section{(F. Harmsen van Beek).}

Rede

In verkorte vorm uitgesproken bij het afscheid als gewoon hoogleraar genderstudies aan de Universiteit Maastricht op 13 juni 2014.

Door

Prof. Dr M.J.H. (Maaike) Meijer

ISBN: 9789056814311

NUR: 740 
Zeer geachte dames en heren collega's, promovendi, vriendinnen en vrienden,

De biografie mag zich in Nederland verheugen in grote belangstelling van de zijde van lezers en media. Er worden tegenwoordig veel meer biografieën geschreven dan pakweg dertig jaar geleden en de eventuele onthullingen die erin worden gedaan krijgen zelfs soms voordat een biografie verschenen is serieuze aandacht. Dat was onlangs nog het geval met de ontdekking van Jolande Withuis, dat koningin Juliana tijdens de oorlog diplomatiek en politiek veel actiever was dan de beeldvorming van de brave huismoeder met de prinsesjes opgeborgen in Canada deed vermoeden. 'Terwijl het dertig jaar geleden nog omstreden was of je op een schrijversbiografie - of een biografie überhaupt - zou kunnen promoveren zijn er inmiddels veel doctor-biografen, zoals Mineke Bosch met haar biografie van Aletta Jacobs en mijn eigen promovenda Elsbeth Etty met die van Henriëtte Roland Holst, Koen Hilberdink met Hans Lodeizen, Hans Renders met Jan Hanlo. Dit is een internationaal fenomeen, ook al is Nederland er vrij laat mee en is er al een veel langere Engelse traditie van alom gewaardeerde biografieën. Dichters krijgen daar niet één biografie, maar standaard meerdere.

\section{Populariteit van de biografie}

Mijn eerste vraag is: waar komt deze aandacht voor de biografie vandaan? Hangt hij samen met een nog immer aanzwellende belangstelling voor levensverhalen in het algemeen? Met de internationale ontwikkeling in de geschiedwetenschap, beginnend met de Annales-school, daarna de mentaliteitsgeschiedenis, de gendergeschiedenis en de Alltagsgeschichte, waarin door links-georiënteerde en feministische historici werd aangedrongen op meer studie van menselijke agency, meer aandacht voor de wijze waarop de grote historische omwentelingen aan de basis van de samenleving werden geleefd? Daarom werd gezocht naar nieuwe bronnen, waaruit de levens van mensen die geen koning of veldheer of man waren tot leven kon worden gebracht, hetgeen leidde tot een golf van zogeheten 'micro-histories'. ${ }^{2}$ Is het dan het sneeuwbaleffect van de vele slave narratives die zijn uitgegeven, de dagboeken van landarbeiders,

1 Zie de NOS documentaire over Withuis' onderzoek 'Juliana in de oorlog' uitgezonden 5 maart 2014, 21.25 4 en Withuis Jolande, Juliana's vergeten oorlog. Amsterdam, De Bezige Bij 2014, een voorpublicatie van de in 2015 te verschijnen Juliana-biografie.

2 Over het groeiende belang van egodocumenten voor historici: Gert-Jan Johannes en Rudolf Dekker 'Het egodocument: stiefkindje of oogappel?' in: Vooys 17 Utrecht 1999: 22-29 
de ego-documenten van vrouwen - want de feministische slogan 'het persoonlijke is politiek' is inderdaad eer aangedaan ${ }^{3}$ - van seksuele minderheden, de dagboeken van joodse onderduikers zoals Anne Frank en holocaust overlevers als Primo Levi waar we nog steeds in zitten als in een uitdijend universum? Het levensverhalen-genre wordt overigens even druk beoefend door mensen die niet tot 'minderheden' behoren, denk aan de literatuur over en van reizigers, wetenschappers en popmuzikanten, zoals Bob Dylans autobiografische Chronicles. De biografische en autobiografische golf beperkt zich dus niet tot de jaren zeventig en tachtig, de bloeitijd van de protestculturen. De Amerikaanse feministische theoretica Nancy Miller ziet in de jaren negentig

the spectacular rise of the memoir, which (along with biography) became the most popular (and symptomatic) literary genre of our contemporary culture. ${ }^{4}$

En Cora Kaplan voegt daar instemmend aan toe:

With its glitzy new profile, all personal narrative seemed to be in demand - autobiography, confession, memoir, some told-to, some ghosted, it hardly seemed to matter - rolled from the trade presses into the hands of hungry readers establishing a trend that has bridged the old and the new century. ${ }^{5}$

Onlangs zond de VPRO een voortreffelijke achtdelige internationaal geproduceerde tv-documentaire uit, 14-18 De eerste wereldoorlog, waarin het verhaal van die oorlog hoofdzakelijk wordt verteld door de dagboeken, brieven en ansichtkaarten van de soldaten die hem uitvochten; het persoonlijke document lijkt de manier geworden om de geschiedenis te beoefenen en de mentaliteit van mensen die vroeger leefden van dichtbij te benaderen. Maar het zijn niet alleen de sociale- en protestbewegingen, de geschiedwetenschap en de populaire geschiedenis waarin het human interest zijn rol heeft opgeëist. Ons medialandschap is vol human interest, meer dan ooit. Op televisie kijken

3 Zoals Zami van Audre Lorde (1982), Claiming An Identity They Told Me To Despise van Michelle Cliff(1980), dagboeken van spraakmakende feministes als Jill Johnston en Kate Millett en vele andere. In Nederland is Anja Meulenbelts De schaamte voorbij (1976) het bekendste voorbeeld.

4 Miller, Nancy, But Enough About Me. Why We Read Other People's Lives, New York, Columbia University Press 2002

5 Kaplan, Cora, 'Examined Lives' [review van Miller (2002)] in: The Women's Review of Books 20, 2 (Nov. 2002): $11-12,11$ we naar programma's als 'Help mijn man is klusser', naar 'Spoorloos', naar Frans Bromets burenruzies, naar de rijdende rechter die overal conflicten oplost, naar 'Het familiediner', naar 'Ik vertrek' waar we zien hoe Jan en Annie een nieuw bestaan opbouwen door een hotel in de Bourgogne te beginnen. De levensverhalen van Jan en Annie - of, modern, van Annie en Jan - stuiteren op alle zenders op je af. Het lijkt wel of alles wordt voorzien van een persoonlijk stempel. Als je een pak melk koopt staat daar tegenwoordig ook vaak een foto op van Annie en Jan, het boerenechtpaar dat de melk geproduceerd heeft, terwijl de koe misschien toch meer als de ware producent kan gelden. En ook in kwaliteitskranten rukt deze trend om elk onderwerp te brengen als de belevenis van een specifiek individu op. 'Binnenkijken' is een NRC rubriek waarin we een bijzonder interieur van (bijna altijd) een echtpaar bekijken en dat een fabriek of kerk tot trendy woning heeft verbouwd; De reeks Het laatste woord was een vaste NRC rubriek van Gijsbert van Es over iemands levenseinde, ondertiteld 'de kunst van leven met de dood'. Die reeks is nu vervangen door een soortgelijke serie, 'De derde helft', over hoe te leven na het 65 e levensjaar. De rubriek 'Mijn carrière' draagt letterlijk als onder titel 'Hoe doen zij het?' Er lijkt kortom een onstilbare behoefte te zijn kennis te nemen van het leven van anderen. Er is een interessante film over, Das Leben der Anderen - die veel dieper gaat dan zijn onderwerp, de afluisterpraktijken van de Stasi in de voormalige DDR. ${ }^{6}$ Het gaat ook over de psychologie van dit constante afluisteren. Over hoe de afluisteraars alleen nog maar leven als voyeurs, een leven by proxy, verdaan met het zinloze werk van het paranoïde gluren naar het leven van anderen.

Human interest lijkt een allesoverheersend communicatiemodel geworden. Belangrijk is daarbij dat de aandacht voor onze medemens heel horizontaal gericht is. We kijken niet meer alleen naar beroemdheden, machthebbers en ideaaltypische voorbeelden, maar juist ook horizontaal naar gewone levens van gewone anderen. We leven steeds meer by proxy. Als je een magazine opslaat, televisie kijkt of de krant leest staat het water der ditjes en datjes van Annie en Jan je meteen aan de lippen. Veel onderzoekers van nieuwe media hebben ons al verteld hoe het horizontaal communiceren, het facebooken met vrienden, het bloggen, het Linked Innen een allesverslindend tijdverdrijf is geworden. ${ }^{7}$

6 Deze prijswinnende film is van 2006, het debuut van regisseur Florian Henckel von Donnersmarck.

7 Zie ledereen voyeur van mijn Maastrichtse collega lke Kamphof (2013) die dit alomtegenwoordige kijken naar de ander zeer genuanceerd behandelt. Zie ook Sherry Turkle, Alone Together. New York: Basic Books 2011 
Het gaat me nu echter niet om een oordeel over deze pervasieve tendens in de media. Ik zit er zelf tot over mijn oren in, net als u waarschijnlijk. Ik lees de NRC tenminste van voor tot achter. Misschien vertellen Jelle Brandt Corstius' televisiereizen door Rusland waar hij spreekt met gewone mensen ook wel veel meer over Rusland dan een politieke analyse. ${ }^{8}$ Misschien geeft Het pauperparadijs van Suzanne Jansen wel een veel pakkender beeld van de lange geschiedenis van de daklozenkolonie in Veenhuizen, juist omdat het ook een familiegeschiedenis is met een persoonlijke invalshoek. Maar helpen deze fenomenen ook om de groeiende aandacht voor het genre van de biografie te duiden? De biografie is - dat is het verschil met de representatie van het leven van anderen in de media - geen horizontale benadering van het leven van anderen: biografieën worden nog steeds geschreven over opmerkelijke mensen, erflaters van onze beschaving, Joke Smit, Jaap en Ischa Meijer, Annie Schmidt, waarvan de kunstenaars meer in het bijzonder de dichters hier mijn aandacht zullen krijgen. Maar de toon van de biografie is wel veranderd. Het zijn allang geen moderne heiligenlevens meer. Bewondering en idealisering hebben plaats gemaakt voor nuance en realisme. In de receptie van mijn Vasalis-biografie, die in 2011 verscheen, viel mij wel op dat veel lezers ook ontroerd waren juist door de gewone levensdilemma's van Margaretha Leenmans (zoals Vasalis' meisjesnaam luidde) - en er een horizontale ervaring bij hadden als ik het zo mag noemen. De receptie van een biografie kan dus wel geheel of gedeeltelijk 'horizontaal' zijn, maar een biograaf die daar alleen maar voor gaat doet zijn of haar werk niet. De biograaf van een kunstenaar moet namelijk in mijn ogen twee biografieën schrijven: een van de mens en een van diens kunst en hoe die twee met elkaar verbonden zijn. Je hoopt als biograaf dat de lezer niet alleen het eerste - het Annie en Jan gedeelte zal ik maar zeggen - van je biografie leest maar ook het tweede gedeelte, de biografie van die kunst. Daar ga ik zo dieper op in.

\section{Steeds autobiografischer}

Ik wil eerst nog een ander, meer literair fenomeen aanwijzen dat kan helpen om de groeiende belangstelling voor de biografie te duiden. Dat is de internationale trend van het almaar autobiografischer schrijven, 9 die we ook in de hedendaagse Nederlandse literatuur zien.

8 Jelle Brandt Corstius Van Moskou tot Magadan (zesdelige documentaire, uitgezonden door de VPRO in 2009) en Van Moskou tot Moermansk (idem, uitgezonden in 2010)

9 Bijvoorbeeld Amy Homes, The Misstresses' Daughter, Julian Barnes Levels of Life, de driedelige autobiografie van John Coetzee - Boyhood, Youth en Summertime.
Autobiografische romans rukken op, zijn geliefd en vallen veelvuldig in de prijzen. Tonio van A. F. Th van der Heijden (2011), waarin de auteur rouwt om de dood van zijn zoon, is een recent voorbeeld, Knielen op een bed violen van Jan Siebelink (2006) vond een enorme weerklank evenals de verklaard autobiografische tweedelige roman Pier en Oceaan van Oek de Jong (2012). Autobiografisch schrijven is op zichzelf allerminst nieuw, maar het lijkt frequenter en vooral onverhulder plaats te vinden. Jan Wolkers heeft veel op zijn eigen leven geënt werk maar zo werd het bij verschijnen niet gepresenteerd. Ik Jan Cremer was een provocatie in 1964, niet alleen vanwege de ongelikte stijl en macho-thematiek ervan maar ook vanwege het ostentatief autobiografische karakter. Belangrijke stations in het expliciet gebruik maken van het eigen leven waren de brievenboeken Op weg naar het Einde (1963) en Nader tot $U$ (1966) van Gerard Reve. ${ }^{10}$ Het Bureau van Voskuil (1996-) heeft ook een belangrijke rol gespeeld in het geaccepteerd raken van de onverhuld autobiografische modus. Frida Vogels, wier complete dagboeken nog steeds aan het verschijnen zijn, werkt in dezelfde lijn. Doeschka Meijsings $100 \%$ chemie (2003) is een waar gebeurde familiegeschiedenis. Peter Terrin Post Mortem (2012) is het sterkst mij bekende staaltje: Terrin heeft zijn vierjarige dochtertje verloren aan een hersenattaque en schrijft een boek over een schrijver die zijn dochtertje heeft verloren aan een dergelijke attaque en die daarover een boek schrijft: dat is autofictieve meta-fictie. "Veel van Connie Palmens werk is onverhuld autobiografisch en ook Anna Enquist heeft het verlies van haar dochter expliciet tot literair onderwerp gemaakt. Opmerkelijk genoeg wordt het vrouwen echter meestal aangerekend wanneer ze autobiografisch schrijven. Enquist en Palmen zijn er onevenredig hard op aangevallen, terwijl het bij de genoemde mannelijke auteurs, Van der Heijden, Siebelink en De Jong juist bijzonder wordt gewaardeerd. De dubbele standaard in de literaire kritiek is nog steeds niet verdwenen. ${ }^{12}$

10 Zie de dissertatie van Edwin Praat, Verrek het is geen kunstenaar. Gerard Reve en het schrijverschap. Amsterdam, UvA interne publicatie 2011, p 135-200. Praat analyseert hoe Reve de aanvankelijk veronderstelde authenticiteit van zijn autobiografische boeken zelf voortdurend en onderuithaalt en hoe hij door volkomen fictieve autobiografieën (als 'Levensloop van de schrijver' in Een circusjongen) elk onderscheid tussen literatuur en leven tart.

11 Zie de bespreking van Post Mortem door Bart Temme, 'Herinneringen als clusterbommen' in: Tzum literair weblog maandag 11 juni 2012

12 Zie Leon Hanssens hoofdstuk 'Het kind vrijlaten' over het literaire thema van het verloren kind en de seksistische wijze waarop dat in de kritiek werd ontvangen toen vrouwelijke auteurs het behandelden. In: Een misverstand om in te geloven. De poëzie van M. Vasalis. Amsterdam, Polak en Van Gennep 2007. p 168-177 
De verschuiving in de beoordeling van het werkelijkheidsgehalte van literaire fictie is mooi te zien als je de receptie van Arthur Japins roman, De zwarte met het witte hart uit 1997 vergelijkt met de receptie van Oorlog en Terpentijn van Stefan Hertmans uit 2013. Japins boek handelde over de ontvoering van twee zwarte prinsjes uit Afrika, die in de negentiende eeuw cadeau werden gedaan aan Willem I. Het schetst een aangrijpend gepersonaliseerd beeld van de Nederlandse slavenhandel in Afrika en Suriname en het alledaags racisme in Europa. Japin baseert zich op historische bronnen en werd om die reden gediskwalificeerd voor de Librisprijs van 1997. Het was geen literatuur, meende de jury, omdat er historische bronnen aan ten grondslag lagen. Nu wordt Stefan Hertmans, die claimt de dagboeken van zijn grootvader intensief te hebben gebruikt als bron voor zijn roman Oorlog en terpentijn uitgedaagd om precies te vertellen hoe letterlijk en getrouw hij die dagboeken heeft gevolgd. ${ }^{3}$ De interviewster Jannetje Koelewijn vraagt hem:

\section{Bestaan de schriften wel of niet?}

Hij geeft geen antwoord en begint te vertellen over de techniek van het vertellen: soms maakt hij van één zin van zijn grootvader een apocalyptische scène, soms brengt hij een verslag van zijn grootvader terug tot één zin. 'Ik trek de harmonica open waar hij hem dicht doet en andersom.'

Koelewijn verbaast zich over 'het uitgesproken oedipale karakter dat Hertmans de relatie van zijn grootvader met diens moeder meegeeft.' Als ze bij een onweer samen naar binnen moeten vluchten zou Hertmans' grootvader hebben geschreven: 'Nu zij, mijn schoone moeder, mij zo tegen hare borst drukte, overspoelde een groot gevoelen mij, en mijn hart ging geweldig tekeer.'

Koelewijn: Staat dat echt zo in dat schrift?

Hertmans: 'Dat zou ik moeten nakijken.'

En dat gaat u niet doen.

'Zelfs de citaten geef ik wel eens een tik. Misschien heeft mijn grootvader het niet letterlijk zo geschreven, maar het is wel waarachtig wat er staat. Zo stond hij tegenover zijn moeder. [...]

13 Arnon Grunberg hoopte in een eerder (in de NRC van 28 maart 2014) dat de dagboeken fictief zouden zijn, dan zou Hertmans in zijn ogen een betere schrijver zijn. Koelewijn voelt Hertmans nader aan de tand: Jannetje Koelewijn, 'Ik houd mijn waarheid verborgen,'[interview met Stefan Hertmans] in: NRC Handelsblad 3 mei 2014 p 14
Vragen stellen over de realiteit van een literair werk is...

...typisch voor deze tijd als $u$ dat bedoelt. En dat komt doordat we het vertrouwen in literatuur verloren zijn. Literatuur gaat over ervaringswaarheid. Mijn boek is volkomen waarachtig maar...

...niet waar.

Hertmans: Wel! Wel! Clear cut is Oorlog en Terpentijn voor tachtig procent waar.

Dit laat zien hoezeer het tij aan het keren is. In 1997 mag het niet historisch waar zijn, nu moet het letterlijk waar zijn. Eerst zijn historische documenten als bron taboe, nu moeten ze fysiek getoond worden. Hertmans dient beide partijen van repliek. Hij verdedigt zijn literaire omvormingsactiviteit, zijn kunstenaarschap, te vuur en te zwaard en tot in detail.

Heden ten dage geldt: hoe meer werkelijkheid, hoe meer biografie en autobiografie, hoe beter. Dat constateerde mijn collega Agnes Andeweg al in 1998, toen zij de Libris-jury kapittelde over die merkwaardige diskwalificatie van Japin:

De jury was daar duidelijk bezig met een achterhoedegevecht. De realiteit rukt nu eenmaal steeds verder op in de literatuur, net zoals 'reality-tv' zich definitief genesteld lijkt te hebben op de televisie. 'Echt gebeurd' is een aanprijzing geworden, en het onderscheid tussen feit en fictie lijkt steeds verder te vervagen. Of dat nu in de vorm van historische romans is (Wisselkind van Basha Faber, Heren van de thee van Hella Haasse, et cetera) of in de vorm van sterk op de autobiografie van de auteur berustende 'romans' [...] als [...] I.M. van Connie Palmen. Er zijn legio voorbeelden van die dit-is-echt-gebeurd-trend in de literatuur. De alom geroemde kantoorsoap van J.J. Voskuil (goed voor de Librisprijs van 1998) bijvoorbeeld, de kindermoordenaars in Een hart van steen van Dorrestein, en het laatste boek van Zwagerman, waarin een doorzichtig laagje fictie over het radioprogramma 'Ophef en Vertier' gesmeerd is. Daar valt niet tegenop te jureren en dat moet men ook vooral niet proberen. ${ }^{14}$

Het gaat erom, aldus Andeweg, of er een meeslepend geschreven boek is ontstaan. Feit of fictie is niet devraag: de feiten zijn altijd gefictionaliseerd, het enige criterium dat blijft gelden is het literaire criterium van de stijl

14 Andeweg, Agnes, 'Dit Is Echt Gebeurd,' in Vooys 16, 4: 50-51. Utrecht 1998 
en de compositie. ${ }^{15}$ Het is die waarheid waarop Hertmans zich beroept. In feite gebruikt hij in zijn omlijstend verhaal over de dagboeken van zijn grootvader een bij uitstek literaire kunstgreep, al bekend sinds de romantiek: de brief in een fles gevonden, het opgegraven oude manuscript. Die topos is al bijna zo oud als de literatuur zelf en stamt uit de orale traditie: ik vond of hoorde een oud verhaal, zo luidt de topos, ik vertel het verder. De negentiende-eeuwse romanschrijfsters tot en met Henry James wisten nog dat het indirect, gemedieerd vertellen - het verhaal inbedden in een ander verhaal een extra laag van intensiteit aan de geschiedenis verleent - denk aan de compositie van Wuthering Heights, van James' The Turn of the Screw, allebei verhalen-in-eenverhaal. In hoe Hertmans zijn verhaal uitstelt en op spanning brengt, door te zeggen dat hij de schriften van zijn grootvader al heel lang had, dat hij ze niet eerder kon of durfde te lezen, daarin sluit hij naadloos aan op de literaire kunstgrepen van Emily Brontë en Henry James.

Maar de topos van het gevonden verhaal drukt in mijn ogen nog iets anders uit, namelijk: dit verhaal is niet van mij. Ik bezit het niet. Het is mij geschonken, het is iets anders dan ik ben, het overkwam mij. Dat zegt iets over het geheim van de kunst. L'art est une oiseau rebelle. Kunst is hard werken maar komt ook uit een geheimzinnige bron, uit inspiratie, uit het gunstige moment waar de Grieken een godheid voor hadden die zij 'Kairos' noemden. Joke Hermsen wijdde onlangs een interessant boek aan deze broer van Zeus met zijn kale hoofd en daarop slechts een enkele lok haar. ${ }^{16}$ Aan het kruisverhoor waaraan Hertmans wordt onderworpen zien we dat de magie van de kunst, de anders-heid ervan, heden ten dage soms niet meer herkend wordt. Ik zie het als een taak van de kunstenaarsbiografie om het besef van die 'otherness' van de kunst weer terug te brengen.

\section{Kairos, duende en eindigheid}

Met zoveel autofictie heb je bijna geen biografieën meer nodig, zou je kunnen zeggen. Kan de biograaf van A. F. Th. van der Heijden de Tonio-episode niet overslaan, daar A. F.Th. die zelf al voldoende heeft behandeld? Kunnen we in plaats van het hoofdstuk 'Anna Enquist verliest haar dochter' niet beter een paar van haar prachtige rouwgedichten citeren die het bovendien nog allemaal zoveel pregnanter en beter

15 Naar aanleiding van Serge Doubrovky's roman Fils (1977) werd in Frankrijk de term 'autofiction' gemunt voor literatuur die het onderscheid tussen feit en fictie onderuithaalt. Het tijdschrift Armada wijdde er een themanummer aan: Autofictie. Armada $16 \mathrm{nr}$ 61, December 2010

16 Joke Hermsen Kairos. Een nieuwe hevlogenheid. Utrecht, De Arbeiderspers 2014 zeggen? Nee. En de crux is inderdaad dat de gedichten het allemaal zoveel pregnanter en beter zeggen. Daarom moet de biografie van Anna Enquist laten zien hoe de auteur er literatuur van heeft kunnen maken. Literatuur is en blijft vorm en stijl, hoe autobiografisch ook, en juist door die stilering wordt het iets anders dan autobiografie. Het leven zelf is een rommelig en redelijk ongestructureerd zootje. We weten niet waar het heen gaat - dat weten we wel, het duurt nog een tijdje en daarna loopt het gegarandeerd verkeerd af en daar proberen we zo weinig mogelijk aan te denken.

Literatuur wordt gestructureerd door de eindigheid van de tekst, die deze in vorm drukt en betekenis genereert.17 Autofictie is een subgenre van realisme, een beproefde literaire vorm, een representatie van werkelijkheid, niet de werkelijkheid zelf.18 Literatuur kan een werkelijkheidsillusie scheppen. ${ }^{19}$ De autobiografische modus is een vorm van literair realisme, waarbij de schrijvers het scheppen van de werkelijkheidsillusie op de spits drijven, zo dat veel van hun lezers 'erin trappen' zal ik maar zeggen en dat is dan ook precies de bedoeling. Literatu ur kan zoveel effect hebben, de lezers zo raken, omdat wij kunnen verdwijnen in die wereld waarvan we eerst nog wel weten dat die van een ander is maar dat verliezen we al lezend uit het oog. Lezen is geen enkele reis meer naar Das Leben der Anderen maar een retourtje dat bij jezelf eindigt.

Het is duidelijk dat heel veel mensen de rouw om een gestorven kind hebben beleefd via Tonio van Van der Heijden, via gedichten van Enquist en dat deze auteurs duizenden mensen hebben getroost, juist door vorm te geven aan iets wat zo verschrikkelijk is dat het zich in het werkelijke leven als een vormloze ramp manifesteert, dat de beroofde ouder als een ondraaglijke lawine bedelft. Wie erover leest krijgt zelf weer vorm. Hij of zij ervaart gaandeweg dat het verhaal of gedicht niet alleen over die auteur gaat, maar ook over hem of haar. De lezer wordt gered door de vorm. Dat is het literaire proces van transfer.

17 Frank Kermode The Sense of an Ending. Studies in the Theory of Fiction. Oxford University Press 1967 en Barbara Hernnstein Smith Poetic Closure. A Study of How Poems End. Chicago University Press 1968.

Zie een krachtige verwoording daarvan in Pam Morris Realism (2003) p. 4

19 Roland Barthes noemde die het effet du réel. 
Dat blijft volledig intact, hoe autobiografisch een tekst zich ook presenteert. ${ }^{20}$ Ziedaar het kwalitatieve verschil van kunst met de doordenderende human interest die ons aan alle kanten omringt.

Het meest cruciale element van kunst is de eindigheid van het werk zei ik. Doordat het werk begrensd en af is wordt het ontheven aan de nimmer eindigende alledaagse communicatie. De kleine dood - het einde - brengt het werk paradoxalerwijs pas echt tot leven. Door het einde kan immers betekenis worden gecreëerd. Onze eigen eindigheid is meestal nog niet aan de orde als we een boek openslaan: die proberen we in het dagelijks leven van ons af te houden. Maar de kunst herinnert ons eraan op een manier die we kunnen verdragen. Het helpen verdragen van de dood is mogelijkerwijs het programma van veel kunst. lets kan zo mooi zijn dat het ons met de dood verzoent - muziek, een gedicht, autofictie of een roman die verschrikkelijk droevig en daarom prachtig is - een complexe emotie die Vasalis in het vers 'Fanfarecorps' ooit uitdrukte met de regel 'ik voelde mij bedroefd en goed. ${ }^{21}$ Door kunst ervaar je de sterfelijkheid 'by proxy'. Dit bedoelde Federico Garcia Lorca in zijn essay over 'duende' - een begrip dat het overslaan aanduidt van de vonk tussen performer en publiek in dans of muziek. Opeens kan 'het' er zijn, de verbinding, de ontroering, de schoonheid die het publiek treft en in een staat van wensloosheid brengt omdat het even perfect is. De Spanjaarden roepen op dat moment 'dio' en dat betekent God. God bemoeit zich er even mee, komt langs, blaast erin. Voor Lorca hangt het moment van manifestatie van deze duende, het moment waarop de kunstenaar boven zichzelf uitstijgt, samen met lichamelijkheid en daarmee met het besef van sterfelijkheid. Dat wordt tegelijkertijd opgeroepen en gestild. Voor Lorca manifesteert deze openbaring zich dus altijd in een performance, in een lichamelijke setting. ${ }^{22}$

20 Literaire transfer is iets anders dan 'herkenning', waar zowel in de neerlandistiek van de jaren zestig als in de beginjaren van de feministische literatuurkritiek veel over is geschreven. In mijn ogen is herkenning een te vage term om de confrontatie met een tekst die je rakt mee aan te duiden. Herkenning

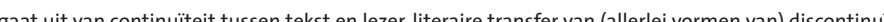
ger. eit. Zie mijn De lust tot lezen (1988) p. 230-234. Dat de literaire transfer intact blijft ook als een tekst zich als autobiografisch presenteert betekent dat de invloedrijke theorie van Philippe Lejeune (1975), die de term 'autobiografisch pact' introduceerde aan herziening toe is. De lezer moge wel aan het boek beginnen met de verwachting 'dit is een echte persoon en dit allemaal echt zo gebeurd' maar vanwege de literaire vorm vergeet hij/zij de afspraak. Ook autobiografische teksten worden gestructureerd door vorm, stijl en verteltechniek.

21 Zie Maaike Meijer, 'Hoor die muziek. Poëtica's van droefheid en troost,' in: Armada 12, 42 maart 2006 70-81

22 Lorca, Federico Garcia. In Search of Duende. Prose selections, edited and translated by Christopher Maurer. London: New Directions 1998
Maar voor mij hoeft dat niet. Doordat de tekst gestructureerd wordt door zijn einde komt de sterfelijkheid erin. Er is ook duende in het lezen, kairos, het moment dat de vonk overspringt. Ik noem dat dus de literaire transfer.

Tot zover mijn excursie naar het toenemende belang van de autobiografische modus zowel in als buiten het literaire domein en naar de roep om meer werkelijkheid in de literatuur. Hij brengt ons zeker dicht bij een verklaring voor de populariteit van de schrijversbiografie. Lezers willen kennelijk meer weten over het echte leven en over de bronnen die de schrijver heeft gebruikt. Succesvolle schrijvers zitten voortdurend bij DWDD of Pauw \& Witteman - waar ze soms even iets mogen zeggen over hun werk, maar vaak worden ondervraagd over de ditjes en datjes van hun gewone leven, hun muziekvoorkeuren en of ze van Thais eten houden. ${ }^{23}$ De biografie is geen televisie maar het is wel een medium, en geeft nog explicieter dan tegenwoordig in de literatuur het geval is de illusie van het echte leven. ${ }^{24}$ Daarnaast is een biografie zelf ook een levensverhaal met een begin en een eind, en bedient de biograaf zich ook van modes of emplotment, van cliffhangers en andere technieken van spanningsopbouw. Misschien is een biografie wel eenvoudigweg het zoveelste levensverhaal dat toevallig over een kunstenaar gaat. Maar nee, daar doe ik het niet voor. Ik verwacht meer ambitie van lezers van kunstenaarsbiografieën. En de biograaf kan ook meer dan blindelings voldoen aan de aanzwellende vraag naar human interest en biografische achtergronden. Hoe zorgt zij er dan voor dat zijn/haar biografie niet alleen maar een aansprekend levensverhaal is, dat bovendien als neveneffect kan hebben dat literatuur in zijn geheel in het human interest domein wordt opgezogen? Hoe behoedt de kunstenaarsbiografie de kunst? Hoe bezweert zij het gevaar haar lezers alleen maar mee te nemen naar een enkele reis Leben der Anderen? Daarmee ben ik aangekomen bij de vraag die ik in dit afscheidscollege wil beantwoorden. Wat is de taak en de zin van een dichtersbiografie? Hoe kan het genre ontsnappen aan alleen-maar-levensverhaal te zijn, of erger, aan voyeurisme, aan petit histoire.

23 Peter Buwalda heeft in zijn Kellendonklezing onlangs het mediacircus dat de 'bestselleritis' met zich meebrengt geestig en met veel zelfspot op de hak genomen: De wethouders van Juinen, Nijmegen 2013

24 De illusie, want de biografie heeft in mijn ogen veel gemeen met realistische fictie. 


\section{Vasalis}

In 2011 verscheen mijn biografie van de dichter M. Vasalis en daarin heb ik geprobeerd te ontsnappen aan het loutere levensverhaal door steeds te zoeken naar wat Vasalis als dichter dreef. Het echte onderwerp van mijn biografie was die bij tijd en wijle hallucinante poëzie, die van elders lijkt te komen, en Vasalis heeft dat ook zo ervaren. Ze bedacht haar verzen niet, die werden haar gegeven. In een Engelstalige tekst met jeugdherinneringen, waarschijnlijk geschreven voor haar Amerikaanse vriendin Edna St Vincent Millay, beschrijft ze hoe ze als heel jong kind dat nog amper kon praten 's avonds in bed altijd luisterde naar droeve geluiden: de eenzame kreet van de mosselventer en 'the muted call of the foghorn, plaintive, asking an unanswerable question again and again, and my first poems started.' De misthoorn van de boot die achter het huis vaart is haar muze. Toeoeoeoet. Het heel kleine kind hoort een aanhoudende gedempte vraag in de stem van de misthoorn en daar beginnen de gedichten. Ze beginnen niet met woorden maar met een geluid, dat geheimzinnig, droevig en onbeantwoordbaar is. Ik breng dat in mijn biografie - via omtrekkende bewegingen en onderbouwd met veel meer bronnen - in verband met de melancholie en het doodsverlangen die zoveel van Vasalis' gedichten als een grondtoon doortrekken.25 Elders schrijft Vasalis dat een gedicht 'wortelt in het geheim', dat ze voelt - op dat moment ontstaat een gedicht - maar dat ze niet kent. Het gedicht probeert het te vangen. Het gedicht is de epistemologie van het geheim, het is de expeditie naar het geheim. Mijn biografie ging in feite steeds over de wijze waarop het werk aan de auteur ontsnapte, hoe het werk groter was dan de auteur zelf. Daarmee schreef ik de biografie van een persoon, maar ook de biografie van dat werk, dat aan heel andere wetten bleek te gehoorzamen dan aan die van het mensenleven. Het werd geboren, zeker, maar het is er nu nog steeds. Het is nog niet dood. De biograaf kan zich er altijd diep van bewust zijn dat er iets in de biografie is dat eraan ontsnapt. In vele dichterslevens zit een radical otherness dat niet van het gewone leven is, en dat is de kunst. Nu zult U misschien zeggen dat dit voor Vasalis' werk en dus ook voor haar biografie wel zo kan wezen - Vasalis hield er immers, tot mijn stijgende verbazing, een uitgewerkte romantische poëtica op na, zo een waarin de dichter werkelijk wordt bezocht door de Muze, een other van formaat en in haar geval ook door de heldere droom en de mystieke ervaring. Mijn poëtica van de biografie past wel precies bij deze dichter,

25 Maaike Meijer, M. Vasalis. Een biografie. Amsterdam: Van Oorschot 2011:75 zult $\mathrm{u}$ zeggen, maar toch moest ik daarvoor wel alles wat Vasalis in brieven, dagboeken en toespraken over het ontstaan van haar poëzie zei, plus haar hele oeuvre, bijzonder serieus nemen. Zo kwam ik erachter. Maar werkt mijn biografenprogramma bij andere dichters ook?

\section{F. Harmsen van Beek}

Dat weet ik nog niet, dat wordt een avontuur. Ik ben net begonnen aan een nieuwe biografie van F. ten Harmsen van der Beek, kortweg F. Harmsen van Beek. Zij is minder bekend dan Vasalis, een totaal andere figuur zowel qua werk als qua leven, ze is de geheimtip van de Nederlandse literatuur, een echte writer's writer: zij werd geboren in Blaricum in 1927 en overleed in Groningen in 2009. Ze werd vooral bekend als dichter, als auteur van Geachte Muizenpoot met name, haar eerste bundel uit 1965. Die werd terecht gezien als een literaire sensatie. Daarna volgden intrigerende verhalenbundels Wat knaagt? (1968) en Neerbraak (1969), het prentenboek Gewone Piet en andere Piet (1969) dan Hoenderlust, een heel aparte verhandeling over kippen (1972) en de tweede dichtbundel Kus of ik Schrijf (1975). De titel van dit college 'm'n hart stond van stocht bijna stil!' is een regel uit het vers 'Over berichten die men aan zichzelf kan sturen en hoe ze verder af te handelen' en komt uit Kus of ik schrijf. Het woord 'hartstocht' wordt in deze regel gedemonteerd en de twee onderdelen ervan worden opgenomen in een nieuwe poëtische orde, waarin metrum - mijn HART stond van STOCHT bijna STIL - plus binnenrijm en alliteratie - stond-stocht-stil - hun de-automatiserende werk doen en ons als het ware even een hartstilstand bezorgen. Het is zo'n regel die je, eenmaal gelezen, nooit meer vergeet. Omdat hij onderdeel is geworden van je geheugen breng je hem van toepassing op dingen uit je eigen leven of werk. (Ik hoop dat $U$ na dit college bij uw volgende verliefdheid kunt denken 'Mijn hart staat van stocht bijna stil' dan is de literaire transfer gelukt). Bij mij heeft deze regel ook betrekking gekregen op sommige van mijn ervaringen als biograaf. Als ik nog heel even naar Vasalis mag: op momenten dat ik in Vasalis' dagboeken een droom las die zij vrijwel ongewijzigd transformeerde tot gedicht - zoals onder andere het geval was met het beroemde vers 'Phoenix I' uit De vogel Phoenix, ja, toen stond mijn hart van stocht bijna stil. Het bevestigde een bij mij en veel andere lyriektheoretici bestaand vermoeden dat de retorica van sommige poëzie en die van de heldere droom verwant zijn. Toen ik het intrigerende maar bijna niet te kraken vers 'Uittocht' kon interpreteren op grond 
van de kladversie ervan, idem dito. En toen ik het dagboekblaadje vond gedateerd 12 maart 1932, waarin de jonge Vasalis hevig verlangt naar een groots ideaal om zich in te storten: ze wil de 'schoone roekeloosheid, de zelfvergetenheid'. Dat verlangen wordt opgeroepen door een regel uit een lied van Marlene Dietrich: Ich möchte mich verschwenden. ${ }^{26}$ Dat zich willen vergooien, opbranden in iets groots is een in het leven vrijwel onvervulbare fantasie en veel van Vasalis' poëzie vindt zijn oorsprong in precies dat fantasma. Het overschrijden van grenzen is op allerlei manieren in Vasalis' werk aanwezig. Daar wordt de onvervulbare wens uitvergroot en uitgeleefd. Dat is het kairos-moment van de biograaf duende, als je zoiets vindt. Daarna is het nog de kunst om 'Kairos bij zijn lok te grijpen' zoals Joke Hermsen het noemt, om iets te doen met die vondst zodat je greep krijgt op die geheimzinnige structuur van dit dichterschap, op de fantasmatische wereld waar de kunst vandaan komt. Ik probeerde dit te verbinden met de ontgrenzing, waar veel gedichten van Vasalis rond cirkelen, haar kijken over de rand van de dood, van het voorgeboortelijke (denk aan 'De Idioot in het Bad'), het visioen. En daarom moet de biograaf het werk van de kunstenaar en alle interpretaties die ervan zijn, zeer goed kennen. Daar begint elke biografie.

\section{De dichter en haar worgengel}

Maar nu Harmsen van Beek. Toen in 2012 In goed en kwaad, het verzameld werk van F. Harmsen van Beek verscheen, stond mijn hart ook even van stocht stil. Ik vond daar namelijk op pagina 337 een onbekend gedicht van Harmsen van Beek. Uit 1958, dit is zeven jaar vóór Geachte Muizenpoot. Wat? De oertekst? - dacht ik even, gelijk de archeoloog die ineens op het koningsgraf stuit. Wat ga ik met zo'n gedicht doen in mijn biografie? Omdat in het werk centraal wil laten staan ga ik dit vers eerst met $u$ analyseren:

\section{(DIT IS DE STEM VAN MIJN WORGENGEL:)}

kom

kom bij mij,

kom in tot mijn

bekommering, kom in

26 Het lied is 'ch bin von Kopf bis Fuss auf Liebe eingestellt', destijds een schlager, waarin de vrouw zingt dat de mannen om haar heen zwermen 'wie Motten um das Licht. Sie möchten sich verschwenden' de mannen willen zich doodvliegen in mijn licht. Maar Vasalis hoort en schrijft: Ich möchte mich

verschwenden. Ze trekt de regel dus onbekommerd naar zich toe, pakt alleen het gevoelsmoment eruit. mijn koele kale kamer,

de verlaten kamer waar de

valse vleugels van gazellen

gazig zijn aan glas en

lig

lig neer,

lig bij mij

neer in onzin, lig

witzinnig neer, spil

met mij om, onmachtig wacht

in woordloze verwildering totdat, o

ga nog

niet, ga nog

niet van mij weg,

geef aan de ritseling van

onbenul nog grappigheid, wind

nog niet af. nu zwel, verscheur en

wil geweldiger omhelzen, musiceren, o

verstikkender beween, bewoon en sexueler,

saxofonig streel en stamel, ai, maak nu halfhalzigheid

tweekelig, siamees, afzichtelijk begaafd schreeuw met mij

uit één mond totdat, o god

begeef

niet, nu

nog niet, geef

nog aan vruchtjes

zaadjes, dauw en vrolijkheid, vouw

uit, vocht in, kom! ogenschijn en schaamteloos

beschommel, stotter tot aan stort van tedere beschimmeling

en vrediger, bewaterfiets zeetuinen van verzadiging totdat.

begoochel nu betrekkelijkheid tot

lengte van verwelkte dagen,

wacht

wacht met mij

af, weerzinnig wacht

het schamele afscheid af,

verteder de waanzinnige ontluistering, o

desnoods fluister met mij uit één mond totdat 
de stilte eter, de verslindende verschrikkelijke vleerman

komt, op stijve voeten zeker komt.

zit met mij uit!

Het gedicht heeft een stamelende structuur met zijn regels van ongelijke lengte en zijn doorgaande opsommingen - de eerste punt vinden we pas in regel 21 - bij 'wind nog niet af.' - en dan gaat het weer ademloos door. De klankmuziek zit in binnenrijm en veel assonantie. De vele enjambementen (een enjambement is het doorlopen van de zin aan het einde van de versregel) drijven het vers voort. Die vorm draagt betekenis: het idee van 'doorgaan, doorgaan, niet ophouden' wordt op die manier belichaamd in de vorm. Het vers is een aanspreking van de 'ik' tot de geliefde, zoals met veel liefdesgedichten het geval is. Een apostrofische situatie dus 27: 'kom' ('O jij' is daarin geïmpliceerd), een gebiedende wijs die tot de laatste regel toe - 'zit met mij uit! - wordt volgehouden. De 'ik' nodigt de geliefde bij zich uit, onmiskenbaar om de liefde te bedrijven: 'kom / kom bij mij / kom in tot mijn bekommering - alsof het lichaam van de ik bekommerd is en troost behoeft. Ik hoor echo's van die onovertroffen liefdeszang, het Hooglied, waarin de man en de vrouw elkaar beurtelings aanspreken en oproepen tot het bedrijven van de liefde. 'De Koning heeft mij gebracht in zijn binnenkameren' zegt de vrouw in Hooglied 1:4, ${ }^{28}$ hier gebiedt de vrouw haar minnaar te komen 'kom in/ in mijn koele, kale kamer'. Zij heeft het initiatief.

'lig bij mij/ neer in onzin' begrijp ik als: de liefde is niet efficiënt - vanuit het praktische perspectief is langdurig vrijen onzin - 'spil/ met mij om' roept associaties met verspillen en spilziek op, het is een oproep tot de geliefde om onfunctioneel met haar aan te rommelen. Bij verspillen denk je ook aan het zaad dat wordt verspild, vrijen is de luxe van de verspilling (dat ligt semantisch in de lijn van 'onzin'). Dit beeld van seksueel genot treffen we ook bij de Franse filosoof Georges Bataille voor wie seksualiteit zowel ontgrenzing als verspilling is. In een maatschappij waar alles op nut en controle is gericht is erotiek een gelukkige vorm van zuivere verspilling.

27 In Van Alphen, Duyvendak, Meijer en Peperkamp Op poëtische wijze (1996) hebben wij-in navolging van andere poëzie-theoretici - de apostrofische situatie tot uitgangspunt van onze lyriektheorie genomen.

28 Ik citeer uit de Statenvertaling die de dichter vermoedelijk kende. De nieuwe bijbel vertaling (waar deze regel luidt 'Mijn koning brengt mij in zijn kamers') is pas in 2004 verschenen. 'onmachtig wacht/ in woordloze verwildering' roept de passiviteit van de erotiek op, de overgave. Niet wordt de aandacht gevestigd op de activiteit van de liefdesdaad, het machtige gebaar, maar juist de onmacht ervan, het ondergaan van strelingen, het wachten (dat in de geval de man moet doen), de taal valt weg, verwildering staat tegenover beschaving, orde en controle, maar in de erotiek heerst woordloze verwildering.

totdat, o

'o' is een uitroep van hartstocht, wellicht wordt hier een eerste hoogtepunt bereikt, maar de geliefde mag nog niet weg:

ga nog

niet ga nog

niet van mij weg,

het 'ga door met het minnespel' wordt indirect geformuleerd als: 'geef aan de ritseling van'/ onbenul nog grappigheid'. 'Onbenul' is een nieuwe formulering van de 'onzin' hierboven - ritseling is heel nietig, dus de 'ritseling van onbenul' is in het efficiency perspectief nergens voor nodig. De 'ik' vraagt om daar nog grappigheid aan te geven ook. Flauwekul dus, maar dat is precies wat het langdurige minnekozen vanuit het nuttigheidsperspectief is. Dan wordt de vraag aan de minnaar weer dringend:

wind/

nog niet af, nu zwel, verscheur en / wil geweldiger omhelzen, musiceren, o

Het verzoek is om de liefdesdaad te verhevigen, en dat wordt vergeleken met musiceren. We kennen de vergelijking van het orgasme met muziek in de uitdrukking 'voor het zingen de kerk uit'. Hier krijgt de minnaar uitdrukkelijk het verzoek te musiceren en dus juist niet de kerk uit te gaan. Het domein van muziek wordt verder benut in sexueel saxofonig streel en stamel en daarna komt het zingen - denk ik tenminste - in 'ai maak nu halfhalzigheid / tweekelig, siamees': dat lijkt mij een beeld voor de seksuele eenwording. Als twee halzen er een worden, zoals dat het geval kan zijn bij een siamese tweeling die een lichaamsdeel delen, dan is een hals maar een halve hals. 'schreeuw met mij/ uit één mond': als twee kelen schreeuwen uit een mond, dat is dat weer het delen van een lichaamsdeel maar figuurlijk is het ook het tegelijkertijd schreeuwen, wellicht een gezamenlijk orgasme bereiken. 
totdat, o god

begeef

niet, nu

nog niet

Het 'totdat' markeert denk ik een tweede hoogtepunt. Het woord 'totdat' komt drie keer voor in dit vers en telkens wordt datgene wat op 'totdat' zou moeten volgen (totdat wat?) weggelaten. De ervaring van het orgasme is onuitsprekelijk, vandaar die leegte achter 'totdat'. Maar daarna mag de geliefde nog steeds niet ophouden, hij mag nóg niet weg, ze smeekt hem:

\section{begeef}

niet, nu

nog niet, geef

nog aan vruchtjes

zaadjes, dauw en vrolijkheid, vouw

uit, vocht in, kom!

Dit 'geef nog aan vruchtjes zaadjes' wijst op bevruchting, lijkt me. Die associatie van lichamelijke liefde met plantaardige vruchtbaarheid zit ook in Hooglied, wanneer de vrouw zegt, in Hooglied 7 verzen 11-12: 'Kom mijn liefste! laat ons uitgaan in het veld, laat ons vernachten op de dorpen. [ ...] laat ons zien of de wijnstok bloeit, de jonge druifjes zich opendoen, de granaatappelbomen uitbotten; daar zal ik $U$ mijn uitnemende liefde geven.'

Bij 'stotter tot aan stort' kunnen we ons wel voorstellen wat er gestort wordt. En daarna wordt het vrediger, 'bewaterfiets zeetuinen van verzadiging totdat.' Ik heb zelden zo'n overtuigend beeld gelezen van het langzame lome bewegen, de tevredenheid van na de liefdesdaad. En daar is het 'totdat' weer, waarvan we niet weten totdat wat. Dan komt de crux: 'begoochel nu betrekkelijkheid': tover het besef van de betrekkelijkheid voor me weg.

wacht

wacht met mij

af, weerzinnig wacht

het schamele afscheid af,

verteder de waanzinnige ontluistering, o

desnoods fluister met mij uit één mond totdat de stilte eter, de verslindende verschrikkelijke vleerman

komt, op stijve voeten zeker komt.

zit met mij uit!

Die stilte eter, de verslindende verschrikkelijke vleerman lijkt mij een beeld voor de dood. Rondom de dood is het stil, er is niets dan stilte, dat is het voedsel dat de dood eet. De verschrikkelijke vleerman lijkt me geënt op de verschrikkelijke sneeuwman, afkomstig uit het ijskoude rijk van sneeuw. Vleerman brengt daar het beeld in van een enorme vleermuis, de vleermuis is een nachtdier. De nacht en de dood zijn broeders, per traditie.

Dit einde verandert de betekenis van het gedicht radicaal. De 'ik' gebiedt en smeekt de geliefde steeds maar om het liefdesspel te laten voortduren, want de dood wacht. 'zit met mij uit!' vraagt ze tenslotte. Het leven wordt hiermee voorgesteld als een wachten op de dood 'uitzitten' doe je iets waar je niet veel zin in hebt. Laten we het wachten bekorten door elkaar lief te hebben en weer en weer opnieuw, totdat de dood komt.

Het is een heel teder, hartstochtelijk, expliciet seksueel en uiteindelijk een diep melancholisch vers, waarin seks wordt aangeroepen als troost voor de dood, die het laatste woord zal hebben. Wat hier wordt opgevoerd is een dodendans. Uit de late middeleeuwen zij veel afbeeldingen bekend van dansende geraamten of ontbindende lijken, dan wel mensen die in een reidans worden geleid door de Dood zelf. Ze dansen naar het graf. Vaak is de klassieke dodendans een commentaar op de standenmaatschappij: vorst en bedelaar, arm en rijk, ze worden allemaal gelijk in de dood. Er zijn ook veel literaire vormen van dit Memento Mori en in dit vers treffen we een late nazaat van de Danse Macabre. Maar dit vers is ook een interventie in het genre. Het is geen commentaar op de standenmaatschappij, maar een uitnodiging om van het lichaam te genieten, op de rand van de wanhoop misschien, ondanks de dood.

Ik heb nog niets gezegd over de titel van dit vers, hij staat er als een regieaanwijzing, tussen haakjes (DIT IS DE STEM VAN MIJN WORGENGEL:) Dat wil zeggen dat dit hele vers moet worden opgevat als de tekst die 'mijn worgengel' uitspreekt. Het woord 'worgengel' is bij neerlandici bekend uit een beroemde preek van de negentiende-eeuwse dominee François Haverschmidt, die in zijn jonge jaren bitterzoete versjes dichtte onder het pseudoniem Piet Paaltjes. Hij leed onder zware depressies en hij pleegde tenslotte zelfmoord. In een preek uit 1885 noemt hij de 
dood een worgengel. Hij schildert hoeveel jonge mensen hun leven of hun levenslust al hebben verloren omdat zij 'zich het hartenbloed lieten uitdrinken door de vampier des doods. Hij, de worgengel verstaat geen scherts, wie hem spelend de hand reikt, die laat hij niet meer los, die sleept hij mee tegen wil en dank om in het eind hem neer te stoten in een eigenwillig gedolven graf.'29 De worgengel is het besef van sterfelijkheid of de angst voor de dood. Het is dit aspect van de 'ik' zelf, die deze tekst uitspreekt en vraagt om bemind te worden en de minnaar verzoekt het wachten op de dood met haar uit te zitten. De kleine dood van de seksuele extase is hier het tegengif tegen de grote dood.

Harmsen van Beek laat in dit oudste van haar tot nu toe bekende gedichten meteen en overtuigend zien wat ze kan. Haar techniek is groots, we zagen hoe de neologismen over elkaar buitelen - witzinnig, beschommelen, bewaterfietsen - hoe ze woorden combineert die nooit met elkaar gecombineerd worden - als in 'afzichtelijk begaafd'. Het netwerk van intertekstuele verbanden - hier met het Hooglied en het genre van de danse macabre - wordt haar handelsmerk. Ze doet iets nieuws, zowel technisch als thematisch 30

Op dit moment heeft Harmsen van Beek de voor haar karakteristieke strofenbouw van het archaïserende distichon nog niet gevonden - of ze heeft er voor dit gedicht bewust van afgezien, dat kan ook. Ik laat u nog een fragment zien van het vers 'Lachen bladluis niet' uit Geachte muizenpoot dat die vorm wel heeft, een gedicht dat ook over seks gaat. Maar de representatie van liefde en seksualiteit is daar bijzonder grimmig. Het lijkt alsof de dood al in het leven zelf is binnengedrongen:

Lachen, bladluis, niet

zaniken maar lachen, in een wig van wanhoop, met de kop omlaag en vastgeschoten, lachen tot

29 Uitgangspunt van deze preek was het eerste boek van Samuel 20 vers 3:'Er is maar één schrede tussen mij en de dood.' Rob Nieuwenhuys stelde in 1964 een boek samen met teksten van en over Haverschmidt onder de titel De dominee en zijn worgengel, maar Harmsen van Beeks vers dateert al van 1958. Zij moet dit voor 1964 zeldzame woord dus uit andere bronnen hebben opgediept. Het WN geeft bij' 'worgengel' aan dat het een bijbelse term zou zijn, 'engel die dood en verderf brengt; engel des verderfs' maar het woord komt in de Statenvertaling niet voor.

30 Frida Balk-Smit Duyzentkunst schreef-als enige - over dit vers in 1996 en concludeerde: 'Hier is de coitus poëzie geworden, waarschijnlijk voor het eerst in de geschiedenis.' (Balk 1996: 65) Dat is wat overdreven - bij Lucebert, John Donne en het Hooglied is de coitus ook poëzie - maar dit terzijde. het sterven nader staat dan. En dan is vrede bevrediging godweet, en nader dan die onweelde, die

trossen van ontsteltenis die onze smart zozeer ontsieren, en dan trekt liefde op als nevel boven

slagveld. Dan scharrelt een vogel naar brood of wormen in ogen van gesneuvelden, [...]

\section{Harmsen van Beek 1965:22}

Ik zal dit vers hier niet volledig analyseren, maar wijs er alleen op dat de 'ik' zichzelf hier toespreekt als een bladluis en wel in de gebiedende wijs: 'Lachen bladluis, niet zaniken'. Daar zit een zekere zelfverachting in. Een bladluis is een nietig en gehaat insect. Blijven lachen is de boodschap, tegen een ontzettende somberheid in. Want stel u voor: liefde trekt op als nevel boven een slagveld, waar kennelijk de strijd gestreden is, al enige tijd geleden zoals blijkt uit die vogels die scharrelen naar wormen in de ogen van de kennelijk ontbindende lichamen van gesneuvelden - gruwelijk. En het blijft zo erg.

[...] Dan

stromen hoop, geloof en sexualiteit voorbij aan

de ingetrapte deuren van onze poëtische lichamen: als vuil water aan hoger gelegen puin en Godweet

op die hoogten, op die verheven vuilnisbelten het zoeken naar brood of liefde zuiverheid. Lees nu

nog maar, nog wees niet stukkend of verwoest, maar lachend, want leven een verschuiming, kwijl op

muilen van hebzuchtigheid. (Merkwaardige conceptie, want vreten is stront, au fond, en liefde zaad, en

zaad geld en geld vreten je weet wel.) Ja-

wel. Mij hongert ook, mij dorst en ik verslinger, 
maar onverschilligheid mij nu bevalt en lachen mij

behelst en ik beteken een geraamte $[. .$.

\section{Harmsen van Beek 1965:22-23}

'Dan/ stromen hoop, geloof en sexualiteit voorbij': de gewone combinatie is 'geloof, hoop en liefde'. In deze opsomming is liefde echter door seksualiteit vervangen. Er is, suggereert dat, geen liefde, er is alleen seks. Verderop wordt de stroom van hoop, geloof en seksualiteit vergeleken met 'vuil water'. Er is nog een vergelijking gaande: bij 'ingetrapte deuren' wordt het lichaam vergeleken met een huis, waarvan de deuren zijn ingetrapt. Het intrappen van de deuren betekent schenden van het huis, of de toegang forceren. Een lichaam waarvan de toegang geforceerd is is verkracht. Het beeld is die vuile stroom van 'hoop, geloof en sexualiteit' die voorbij stroomt aan onze lichamen, waarvan de toegang is geforceerd. 'Onze' lichamen staat er: doen de geliefden dit elkaar aan? Later worden de lichamen weer vergeleken met hoger gelegen puin, weer een beeld van verwoesting die associaties wekt met een oorlogsgebied. Nu zijn het wel 'poëtische lichamen' geen gewone lichamen. Dat lijkt me een verwijzing naar de representatie van het lichaam bij Lucebert, die de poëzie en het lichaam zo direct op elkaar betrekt dat ze verwisselbaar worden. ${ }^{31}$ Maar waar Lucebert dat in positieve zin, genietend, extatisch doet, doet Harmsen van Beek het somber en cynisch. Waar Luceberts representatie van de poëzie als lichaam een poëticaal statement is kunnen we dat bij Harmsen van Beek ook zo opvatten. In dat geval is dat een bitter statement dat gericht is tegen het vitalisme en het geloof in de poëzie van de Vijftigers. Het zegt dat de poëzie kapot is, verwoest, verkracht.

$U$ ziet ook dat platte spreektaal wordt vermengd met verheven taalgebruik, een vermenging van registers die altijd aan Gerard Reve wordt toegeschreven, maar waarvan Harmsen van Beek ook de auctor intellectualis kan zijn geweest. Spreektaal - stadsdialect zelfs - is bijvoorbeeld het woord 'stukkend'. Dat kun je alleen maar zeggen van een ding - iets is stukkend - maar hier wordt het gebruikt voor een persoon, die daarmee tot ding gereduceerd wordt. Het spreektalige 'stukkend' staat weer in contrast tot de archaïsch-poëtische zinsbouw die Harmsen van Beek tegelijk gebruikt. Het 'nog wees' in plaats van 'wees nog' is bijvoorbeeld een inversie, net als 'want leven een verschuiming [is]': dat had Leopold zestig jaar eerder nog kunnen

31 Zie onder andere Cornets de Groot, 'Lichamelijke taal (Lucebert)', in: De open ruimte. Den Haag: Bert Bakker/Daamen 1967: 151-160 schrijven. Vulgaire spreektaal is 'want vreten is stront, au fond, en liefde zaad, en // zaad geld en geld vreten en vreten je weet wel.' Dat is een cynische illusieloze blik op genotvolle dingen zoals eten (eten is toch stront) en liefde. Liefde wordt teruggebracht tot seks - dat zagen we hierboven al gebeuren - en seks wordt weer verder teruggebracht tot neuken en het mannelijk liefdesvocht, zaad. Daarmee negeert Harmsen van Beek het vrouwelijke aandeel in en perspectief op het liefdesspel: seks is hier hetzelfde als zaad en deze reductie maakt de vrouwelijke partner zichzelf onzichtbaar. Zaad is geld is de kortste samenvatting van een conservatieve wederzijdse uitbuitingsrelatie van mannen en vrouwen: als hij mag neuken krijgt zij geld: dit kan verwijzen naar gewone prostitutie, maar ook naar het maîtresse-schap, of naar het klassieke huwelijk waar de vrouw voor haar geld afhankelijk is van de mate waarin zij mannelijke behoeften kan bevredigen, een relatie die door feministen van alle tijden terecht ook als een vorm van prostitutie wordt gezien. En geld is weer vreten, en zo is deze treurige cirkel dan rond. Na deze vulgariteiten is er weer een abrupte registerwisseling: 'Mij hongert ook, mij dorst' is archaïsch, zelfs bijbels: Jezus zei 'mij dorst' toen hij aan het kruis hing, en denk verder aan 'hongeren en dorsten naar de gerechtigheid'. Deze duizelingwekkende combinatie van het verhevene en het platte dient in mijn ogen net als bij Reve om het 'hogere' of religieuze te revitaliseren door het naar beneden te halen. Daardoor kan het verlangen naar verlossing weer ervaren worden in het moderne leven. Het religieuze wordt door de spreektaal uit zijn fossiele toestand bevrijd. Tegelijk kan zo ook het gewone leven een tragische, in religieuze termen te vatten dimensie krijgen. Op die manier hebben de verschillende registers een functie voor elkaar: zowel het religieuze als het alledaagse worden erdoor herschreven.

Er valt nog veel meer over dit nog langere gedicht te zeggen, maar $u$ bent het vast met me eens dat dit vers veel somberder dan het eerdere gedicht uit 1958. De worgengel van het doodsbesef is hier nadrukkelijker in het leven en al in de seksualiteit aanwezig. Seks is oorlog. In plaats van een troost tegen de dood wordt seks zelf een vorm van verwoesting, een slagveld. ${ }^{32}$

32 Frida Balk Smit Duyzentkunst schreef eerder - Fritzi en de sprookjes. Amsterdam: Thomas Rap 1996 - over onder andere beide gedichten die ik hier behandel mar brengt ze witeindelijk onder in haar werk negatief ten opzichte van de seksualiteit staan en deze zien als exploitatie van de vrouw. Dat lijkt mij niet het geval. 


\section{De kunst centraal}

Maar waarom Meijer, zult u vragen, gaan we nu zo diep op die gedichten in? Je zou het toch hebben over de biografie? Dit nauwkeurig interpreteren kan toch helemaal niet in een biografie, zo'n boek gaat toch niemand lezen? Inderdaad. 'Minder tekstinterpretatie, mevrouw Meijer!' placht mijn uitgever Van Oorschot tegen mij te zeggen, en schrapte minstens vijftig pagina's uit de Vasalisbiografie. Hij had gelijk. Het moet minder dan ik net deed en wie het naadje van de kous wil weten leest de langere versie van de interpretatie maar in een vaktijdschrift. Maar toch zal ik het ook niet doen zoals Annejet van der Zijl, die het beeld van Harmsen van Beek sterk bepaald heeft met haar Jagtlust uit 1998. Jagtlust was een succesvol boek, een documentaire over de kunstenaarskolonie die ontstond in en rond het grote vervallen landhuis Jagtlust dat Harmsen van Beek tussen 1954 en 1970 bewoonde samen met haar zoontje Gilles, vele huisdieren, wisselende geliefden en huurders. Er werden roemruchte en woeste feesten gehouden. Wat Van der Zijl vooral in beeld brengt is de legende van het leven daar. Het gaat over Harmsen van Beeks grote schoonheid, het feit dat vele mannen op haar vielen, de ruime alcoholinname die in het huis plaatsvond kortom het ruige, romantische alsmede ellendige bohemien-leven van een groep schrijvende en beeldende kunstenaars - Harmsen van Beek, broer Hein, haar tweede echtgenoot Remco Campert, de schrijvers Adriaan Roland Holst, Gerard Reve, de tekenaar Peter Vos, de schilder Paul de Lussanet en vele anderen. Het is onderhoudende lectuur, omdat het een leven in beeld brengt dat velen van ons die zelf geen bohemien zijn zal afstoten dan wel fascineren en zulks allebei tegelijk. Het werkt als royalty-watching voor intellectuelen. Je verlustigt je aan alles wat je zelf ook wel zou willen hebben (schoonheid, veel seks, veel talent en uitbundigheid) versus gruwt van alles waarvan je blij bent dat je het niet hebt (verslaving, armoede, zorgen). Het leent zich kortom enorm voor het leven by proxy waartoe de moderne cultuur ons op allerlei niveaus uitnodigt. Van der Zijl baseerde zich veelal op interviews met mensen die er kwamen, of ervan wisten. Ze vertellen herinneringen aan hun woeste jonge jaren. Harmsen van Beek wilde zelf niet meewerken - ze voelde zich bedreigd door de mythevorming rond haar persoon - maar kwam daardoor nog sterker in de positie van degene over wie wordt gepraat, gefantaseerd en gespeculeerd. Van der Zijl citeert soms een stukje gedicht van haar, alsof dit een direct beeld zou geven van de werkelijkheid. Het probleem is dat dit boek dus helemaal niet gaat over
Harmsen van Beeks dichterschap. Dat wordt slechts van de buitenkant bekeken, alsof het een eigenaardigheid is van de excentrieke 'Fritzi'. Nu gebiedt de eerlijkheid te zeggen dat Van der Zijl ook niet pretendeert een biografie te schrijven maar om een sappig journalistiek verhaal te vertellen. Daarin is zij geslaagd. Omdat ik via de erven Harmsen van Beek over andere bronnen kan beschikken, over autobiografische documenten van Harmsen van Beek zelf, over vroege brieven, kortom over de 33 verhuisdozen die pas in 2012 in het Letterkundig Museum gedeponeerd zijn, hoop ik een heel ander beeld te kunnen geven. Ik pretendeer niet dat dat de waarheid is. Ik ben het eens met de biografie-deskundige Hermione Lee dat de beste manier om om te gaan met het labyrint van verhalen dat iemand omringt het bestuderen van dat labyrint zelf is: wie vertelt welk verhaal en waarom?33 Hoe verhoudt dat verhaal zich tot andere verhalen en tot de documenten en de feiten - die zelf soms ook alleen maar in de vorm van een verhaal bestaan? Mythevorming en nieuwe mythevorming, verhalen en tegenverhalen, sterke verhalen en 'ware' verhalen, oude en nieuwe verhalen, vergeten en herontdekte verhalen, verhalen uit de mond van de dichter zelf die het toch wel het beste zal weten (maar hoeveel verschillende verhalen vertellen wij niet zelf over ons bloedeigen leven? Afhankelijk van het moment en van de persoon met wie wij op dat moment praten?) - dat labyrint te tonen en te analyseren is een vorm van waarheid. Ik neem de mythen dus serieus, maar niet door ze te geloven. Dat is mijn methode.

Dan blijft de vraag: welke betekenis geef ik deze gedichten in mijn verhaal? Vertellen ze iets over Harmsen van Beeks seksleven, over de liefdevolle minnaar A. en de daarop volgende ellendeling B.? Nee, hoewel er voor beide rollen voldoende kandidaten voorhanden zijn, nee. Een zo direct verband tussen kunst en leven is reductief en schuift de kunst naar de achtergrond. Deze gedichten vertellen allereerst iets over hoe Harmsen van Beek het vak al meteen beheerst, hoe haar duizelingwekkende spel met intertekstualiteit belezenheid verraadt in literaire en andere bronnen, hoe ze een nieuwe taal voor seksualiteit uitvindt. Hoe ze er kunst van maakt. 'We hebben kunst om niet aan de werkelijkheid te hoeven sterven', wist Nietzsche al Rosemarie Buikema werkte dat uit in een handvest voor de interpretatie van literatuur waarin je het werk niet terugbrengt tot een statement over de werkelijkheid maar je openstelt voor de verkenning van fysieke en onuitsprekelijke ervaringen die erin plaatsvindt, voor de mogelijke

33 Hermione Lee, Virginia Woolf's Nose. Essays on Biography. Princeton: Princeton University Press 2005 
werelden die erin worden opgeroepen, voor de meerstemmigheid en 'otherness' ervan. 34 Buikema ziet het fenomeen van de intertekstualiteit als kern van de artistieke activiteit en daarmee ben ik het eens: het materiaal van de kunstenaar is vele malen groter dan diens persoonlijk leven. Een biograaf moet dat leven zeker onderzoeken, maar zich ook diepgaand onderdompelen in de afzonderlijke werken en hoe de hele kunst en de hele wereld en alwat erin is en vooral wat er nog niet is daarin resoneert en opnieuw vorm krijgt. Je moet je op dezelfde manier onderdompelen in de ontwikkeling van het oeuvre. Bij Harmsen van Beek ben ik daar nu mee bezig. Het distichon bijvoorbeeld (niet toevallig werd dat in de klassieke literatuur vaak gebruikt voor de klaagzang) komt er al vroeg in en wordt op een gegeven moment afgewisseld met andere strofische patronen die een epischer en minder elegisch effect hebben. Er zijn thematische ontwikkelingen: de liefde wordt zoals we zagen in het eerste gedicht totaal anders gerepresenteerd dan in het tweede. Zo zijn er nog veel meer en heftiger ontwikkelingen. Naast deze gedichten staat bijvoorbeeld een parallel en lichter oeuvre van journalistieke stukken die Harmsen van Beek in de jaren 1960-1965 in Vrij Nederland schreef, waaronder een erg grappige column 'Gebakken bloemen. Een gerecht voor kinderen volgens recept van het beroemde tovervrouwtje Ofiti-Pofiti'. (Verzameld werk p. 374) die handelt over het samen met kleine kinderen verzamelen van schermen van vlierbloesem en daar pannenkoekjes van bakken in een deegbeslagje en hoe dat precies moet. Er zijn stukken over kunst, over het werk van Grandma Moses, James Ensor, over bezoeken aan musea, lingerie, kinderliteratuur en wat we nu lifestyle noemen. Zoals Roland Barthes enkele jaren eerder in Frankrijk in zijn Mythologies (1957) korte stukken verzamelde over onderwerpen die varieerden van Charley Chaplin, de Eiffeltoren, de nieuwe Citroen en het schouwspel van het worstelen zo trekt Harmsen van Beek zich ook niets aan van de scheiding tussen kunst en dagelijksheid, tussen populaire en canonieke cultuurvormen, tussen Nederlandse en internationale verschijnselen. Het huiselijke en ambachtelijke van koken, en dingen maken had voor Harmsen van Beek dezelfde status als kunst en literatuur. Ze schreef op een even geestige als serieuze manier over vrouwendingen, maar ze deed dat - heel strategisch - niet op de vrouwenpagina die veel kranten en bladen toen nog hadden. Daarmee zou ze haar symbolisch kapitaal als dichter waarschijnlijk rap verspeeld hebben. Daarnaast staat weer een parallel oeuvre van tekenwerk en illustraties, waarmee ze al in de jaren veertig begon. Ik acht het een van

34 Buikema, Rosemarie, 'Teveel werkelijkheid is dodelijk voor de kunst,' in: TNTL 126, 2 2010: 202-216 de taken van de biograaf - die immers een heel oeuvre onder de loep neemt binnen de context waarin dat ontstaan is - om deze veelheid en dit soort evoluties van techniek, idioom en thematiek die ik in de gedichten demonstreerde te volgen. Een biografie van een kunstenaar moet diens kunst centraal houden. Hoe ontstaat die, uit welke bronnen vloeit die, hoe groeit en ontwikkelt die zich, hoe wordt die ontvangen en welke invloed oefent die uit? $U$ mag mij eraan houden dat ik die kwestie van de registerwisselingen - was dat een innovatie van Reve of van Harmsen van Beek? - tot op de bodem zal uitzoeken. Het leven van iemands kunst is soms korter dan dat van de kunstenaar, ontstaat pas als hij of zij al twintig is, raakt al vergeten terwijl de kunstenaar nog leeft, maar is meestal veel langer: het werk overleeft de kunstenaar. Het is de taak van de biograaf die tweede draad te volgen tot het moment waarop de biografie wordt afgesloten. Wie een kunstenaarsbiografie schrijft, schrijft er namelijk zoals ik zei twee: een van de kunstenaar en een van diens kunst. En het is precies die combinatie die de kunstenaarsbiografie meer maakt dan een goed levensverhaal en zeker meer dan een reeks sappige anekdotes over een excentriekeling. Zeker heb je dingen nodig uit het gewone leven - scholing, lectuur, werk, vrienden en relaties - om het verhaal mee op te bouwen, om het concreet te maken, en om het werk te situeren in een maatschappelijk veld en in een cultureel klimaat. Maar het gaat niet om die persoonlijke details op zichzelf. Als dat wel zo is raak je op een zijspoor en wordt je kunstenaarsbiografie gewoon een goed verhaal, of een vorm van royalty-watching voor de elite. $M$. Vasalis zei al: 'dichters maken hetzelfde mee als andere mensen.' De echte gift van de kunstenaar is het werk en dat is - zei ook weer Vasalis paradoxaal genoeg - persoonlijker dan het persoonlijk leven.

\section{Kunst als instituut: the darling of the forces}

Hoe kun je het werk centraal houden? Daar zitten twee aspecten aan. Het eerste: je kijkt naar de sociologie van het kunstenaarschap, naar hoe en waarom iemand gaat deelnemen aan het literaire spel, hoe het instituut literatuur er in die periode uit ziet, in wat voor bladen of media hij/zij publiceert en waarom, via welke contacten dat loopt, welke respons iemand krijgt en van wie, welke uitgevers zij kiest, welke prijzen zij krijgt, of zij deelneemt aan poëticale debatten en wat het kunstenaarschap voor haar betekent, qua status, qua zelfbeeld en niet te vergeten financieel. Wat betekent het meedoen aan het literaire spel voor dit leven? En welke impact heeft deze kunstenaar op haar beurt 
op het instituut kunst? De metafoor van het spel ontleen ik aan de Franse kunstsocioloog Lahire, die erop wees dat de beroepsidentiteit van schrijver vaak niet vergelijkbaar is met andere beroepsidentiteiten, die vastere voortrajecten hebben en die meer bestaanszekerheid en een duidelijker maatschappelijker positionering opleveren. Het literaire veld is een heel ander veld dan dat van de psychiatrie of de advocatuur. De schrijver, zo betoogde Gillis Dorleijn, is een amfibie, 'die soms in het water voedsel verzamelt, soms op het strand zijn literaire eieren legt.'35 Het is iemand die in twee werelden thuis is. Dat is kunstsociologie, een richting in de literatuurwetenschap die werd geïntroduceerd door de Franse theoreticus Pierre Bourdieu, veel school heeft gemaakt en die zeker een invalshoek in de biografie van een kunstenaar moet zijn. In het geval van Harmsen van Beek moet je kijken naar haar multi-talent want ze is niet alleen dichter, maar ook journalist, tekenaar, verzamelaar, knipkunstenares, naaister van quilts, graveur op beijsde ramen, dat wil zeggen maker van uiterst vergankelijke kunstwerken waartoe ook de vele gelegenheidswerken in woord en beeld behoren. Ze houdt van ambachtelijkheid, van vergeten kunstvormen en tenslotte 'schrijft ze met haar stem' zoals Adriaan Roland Holst vond en velen met hem.

Harmsen van Beek is consequent bezig met het uitdagen van de grenzen van het instituut kunst. Ze wil er ook niet echt bij horen, ze wordt er eerder haast tegen wil en dank in ingelijfd, vanwege haar fabelachtige gedichten, die bij haar debuut meteen als vernieuwend worden herkend. In dat proces van inlijving spelen tal van interessante gender-patronen een rol. Die moet de biograaf ontrafelen. Komt Harmsen van Beeks recalcitrantie tegen de kunst voort uit de onzekerheid waarvan vrouwen van haar generatie last hadden? Uit de vrees het mannenspel niet te kunnen spelen? Of uit een onwil het te spelen, reserve tegen de pretenties van dat spel? Een hekel aan poeha en dikdoenerij? Of komt die voort uit een door haar al jong omarmde interdisciplinaire poëtica waarbij ze geen onderscheid wenste te maken tussen de kinderliteratuur en het tekenen voor kinderen waarmee ze was opgegroeid en waarmee ze haar carrière begon, uit haar verlangen om in het niet gespecialiseerde domein van het kind te blijven, dat nog kan spelen met alles? Het effect van haar intrede in de poëzie was dat ze onmiddellijk als belangrijk dichter werd herkend maar dat gebeurde wel op de manier waarop vrouwen vaak worden ingehaald: een aantal belangrijke recensenten - Bernlef, Schippers,

35 Dorleijn, Gilles, 'De auteur: levende dode en amfibie. Over de wisselende blik van de literatuurwetenschapper en zijn oogkleppen. In: Vooys 28, 2 (2010): 8-19, p. 18. Dorleijn steunt in zijn artikel op Lahire, B. La condition litteraire. La double vie des écrivains. Paris 2006
Lehmann, Nuis en Van Santvoort - vond haar Geachte muizenpoot direct verrassend goed. Bernlef besteedde al voor de verschijning van Muizenpoot zeer positieve aandacht aan haar en meldde dat Hugo Claus haar 'enige jaren geleden' een van de meest originele talenten noemde. Die uitspraak van Claus staat nergens, het is verhaal van-horenzeggen - maar het gaat wel een eigen leven leiden. Het 'Claus, Bernlef, Schippers en Nuis vinden haar goed' wordt een formule. Voorzien van vele stempels van mannelijke goedkeuring mag zij het instituut literatuur betreden, waarvan de toegang door mannen onderling wordt geregeld. Zo ging het in de zeventiende eeuw al met Tesselschade Hooft en Huygens vonden haar goed- met Anna Maria van Schuurman - Cats vond haar goed - en ten tijde van de Tachtigers met Hélène Swarth - Kloos en Van Deijssel vonden haar goed - dus dit patroon dat mannen elkaars oordeel sanctioneren en dat de literatuurgeschiedenis vooral het feit van de mannelijke goedkeuring blijft memoreren is niet nieuw. ${ }^{36}$ Als Pierre Bourdieu bij al zijn aandacht voor hoe het instituut literatuur werkt nu eens wat meer naar gender had gekeken, een factor waar hij met verbijsterende inconsequentie aan voorbij ziet, terwijl het man-zijn toch een gegarandeerde bron van symbolisch kapitaal is, en daarmee een belangrijke voorwaarde voor succes in het literaire veld. ${ }^{37}$ Tot op de dag van heden kan de kritiek seksistische trekjes vertonen en bestaat er een volstrekt ongelijke behandeling van vrouwen bij de grote literaire prijzen. Aan de andere kant krijgen vrouwen die na rijp beraad wel worden toegelaten de status aparte van the darling of the forces, iets wat Harmsen van Beek ook overkwam. Haar darling-status blijkt uit het feit dat zij onmiddellijk door iedereen Fritzi wordt genoemd. Zelf is zij professioneel: ze gebruikt in haar auteursnaam uitsluitend haar initiaal. Dat 'gefritzi' is een familiariteit die men zich uitsluitend met vrouwen veroorlooft. Ik noem dat het Maria Vasalis syndroom. Ergens in de jaren zestig noemde een Vlaamse critica M. Vasalis Maria Vasalis en sindsdien is dat misverstand onuitroeibaar. Waarom hebben ze haar eigenlijk niet meteen Mieke Vasalis genoemd, of Monique Vasalis, vraag je je af.

6. Zie over Swarth Maaike Meijer, 'Hélène Swarth and the construction of masculinity in literary crittcism,' 'in: Rosemarie Buikema and Iris van der Tuin (eds) Doing Gender in Media, Art and Culture. London and New York, Routledge 2009. p. 223-237. Voor de excessieve lof van mannelijke tijdgenoten voor de zusters Anna Roemers Visscher en Maria Tesselschade (die door een lange rij literatuurhistorici is herhaald, alsof wat andere mannen van hen vonden het belangrijikste is dat over hen te melden valt zie Maaike Meijer (ed) The Defiant Muse. Dutch and Flemish Feminist Poems from the Middle Ages to the Present New York: The Feminist Press, 1998.

37 Genderkritische revisies van Bourdieu bieden Lisa Adkins and Bev Skeggs (eds). Feminism After Bourdieu. Wiley/ Blackwell 2005 
Een genderpatroon is in mijn ogen ook dat Harmsen van Beeks 'Goede morgen? Hemelse mevrouw Ping', een allerliefst en toegankelijk vers het populairst wordt, zoals van Vasalis ook meestal de gemakkelijkste en meest ongevaarlijke gedichten gekend zijn.

Eenmaal bekend als dichter blijft Harmsen van Beek vrijwel uitsluitend gecast als dichter, terwijl ze dan toch allang een professioneel tekenares is, essayist en zoals ik zei multikunstenaar. Omdat ze haar artistieke credo van diversiteit en ambachtelijkheid, waarin ze de grens tussen kunst en leven opzettelijk vervaagt, niet uitdraagt als manifest of officiële expliciete poëtica wordt dat credo niet als zodanig herkend. Haar omgang met kunst - meermaals intrigerend verwoord in interviews blijft gecast als een persoonlijke eigenaardigheid. Kijk die gekke Fritzi. Als biograaf ben ik echter van plan haar uitspraken te verbinden met haar werkinterne poëtica, want ik vind Harmsen van Beeks inschrijving in de kunst die meteen een polemische uitschrijving eruit behelst opmerkelijk en ik vat deze op als een commentaar op het instituut kunst. In het schrijversprentenboek dat ik samen met Joost Kircz aan het maken ben hopen we dit perspectief van het recalcitrante multikunstenaarschap duidelijk te maken. Joost Kircz heeft zojuist samen met August Hans den Boef ook een veelomvattend genderkritisch onderzoek gedaan naar de receptie van Harmsen van Beek, dat de literair-institutionele kant en de werking van de literaire kritiek te aanzien van deze kunstenaar verpletterend verduidelijkt. Ik ben nu al schatplichtig aan dat onderzoek. Van zulk voorwerk kan een biograaf alleen maar dromen. Heb mijn dank mannen!

\section{Radical otherness}

Maar er is een tweede aspect aan dit centraal houden van de kunst in de biografie. In het leven van de kunstenaar zit iets dat eraan ontsnapt, de kunst namelijk. Hoe doe je daaraan recht? Ik doe dat door te volgen wat er in het maken van het werk met de kunstenaar gebeurt. Vrijwel nooit is de kunst een voortzetting van het dagelijks leven. Een schrijver wil iets weten, iets ontdekken. Compensatie van het gewone leven is vaak het programma, ontkenning van een probleem, verschuiving ervan, zelfvergroting of -verkleining, afrekening of ontsnapping, het vasthouden van een fantasma - in het werk wordt iets geleefd wat juist niet van het gewone leven is - of maar heel gedeeltelijk. Het gewone leven wordt erin bewerkt, verdrongen, opgehoogd, verplaatst of vervangen. In de kunst kan een melancholie zitten die hij/zij in het gewone leven wegdringt, of juist het geluksgevoel dat elders onbereikbaar is, de agressie of de doodsdrift die alleen maar op papier kunnen worden uitgeleefd. En alle kunst is tegelijk ook onderzoek naar het medium zelf. In Harmsen van Beeks gedichten zie je dat dichten een erudiet en oneindig spel met intertekstualiteit is. Waar kwam dat vandaan? Hoe beleefde ze dat? Over dat proces en die transformatie kan de schrijversbiografie gaan. Dat levert een zeer spannend verhaal op en de kunst blijft centraal. Onlangs slaagde Otterspeer erin om volgens die methode een spannende biografie van Hermans te schrijven. Hij laat zien hoe Hermans in zijn schrijven een intens liefdesverdriet bestreed en daardoor een afstandelijke observatie van zichzelf en anderen aanleerde die hem tot op het bot verkilde en die een structurerende bron van zijn schrijverschap werd. Het werk - het vaak zo ijzige werk - staat bij Otterspeer steeds centraal. Prachtig gedaan. Een minder geslaagd voorbeeld vind ik de biografie van Hazeu over Achterberg. Hazeu gaat elke relatie tussen Achterbergs pathologie - een levenslange onbeheersbare neiging tot geweld jegens vrouwen - en diens dichterschap uit de weg. Die relatie is uiteraard niet een-op-een. De gestorvene is niet Roel van Es, de vrouw die Achterberg vermoordde. Achterberg ontdekt al jong het dichterschap en de daarin al lang bestaande topos van de dode vrouw die tot leven kan worden gewekt door de macht van de dichter. Dat werd de fascinerende manier om zijn pathologie te sublimeren én in stand te houden. Het levert prachtige gedichten op, en intertekstualiteit is hier de sleutel tot de verbinding: Achterberg vindt een vorm, waarin zijn geweldsfantasieën eindeloos kunnen worden beleefd. Hazeu is als de dood dat door het leggen van een verbinding tussen werk en leven Achterbergs kunstenaarschap teniet wordt gedaan terwijl dat kunstenaarschap er precies door wordt verhelderd. Ik heb die Achterbergcasus elders behandeld. ${ }^{38}$ In elke biografie pakt het focus op de kunst uiteraard anders uit. In mijn Vasalisbiografie ben ik er hoop ik in geslaagd te laten zien waarom Vasalis' werk zo levend is gebleven. Omdat het tot stand kwam in een vorm van bezetting of vervoering, die de dichter overkwam. De Muze kwam in meerdere gedaanten - de misthoorn, de droom, de vogel Phoenix - werkelijk op bezoek - of kwam dat heel lang niet - en dat begreep zij niet en het kwelde haar. Hoe dat haar leven mede bepaalde, dat was mijn rode draad. De creativiteit zelf was mijn onderwerp. Vasalis' leven als dochter, zuster, vriendin, als student, moeder, als arts en psychiater kleden de zaak aan, haar

38 Meijer, Maaike, 'Achterbergs autobiografie'. In: Tydskrif vir Nederlands en Afrikaans (TNA) 12, 2:184-20: 
strategische beslissingen hoe zij zich positioneerde in het literaire veld - voornamelijk door zich daaraan te onttrekken - spelen ook een rol, maar de reden waarom ik die biografie schreef was dat ik meer te weten wilde komen over die adembenemende poëzie en dat ik nog een flink aantal ongepubliceerde schatten zou kunnen afdrukken waaraan je precies kunt zien waarom Vasalis ze niet publiceerde: ze fungeren in mijn biografie als een sleutel tot haar dichterschap. De prachtige dagboeken, die ongelooflijke geestigheid en dat grootse karakter kregen we erbij cadeau, maar het was vooral de poëzie en de ontwikkeling waarom het mij ging.

Wat betekent de kunst voor de kunstenaar? Hoe kan zoiets gemaakt worden - die vragen horen centraal te staan in een biografie. Hoe kan de kunstenaar leven met zijn/haar eigen talent, die radical otherness, dat koekoeksei in zijn/haar leven dat een vloek kan zijn maar ook een groot geluk? Dat partieel kan zijn maar ook allesomvattend? Dat een leven kan verlichten, het zin kan geven, dat therapeutisch werkt of - in het geval van grote roem - een last wordt? Dat de kunstenaar kan helpen haar conflicten te ontkennen dan wel op te lossen? Op die manier kan een dichtersbiografie werkelijk gaan over kunstenaarschap en blijft het werk iets anders dan het gewone leven waaruit het zich op een raadselachtige manier heeft losgemaakt. Dat raadsel moet de biograaf vergroten. Dat kan leiden tot een geweldig verhaal. Ziedaar mijn voorlopige biografencredo.

\section{Dank}

En of mij dat lukt? Dat hoop ik maar! In elk geval prijs ik mij gelukkig met het vruchtbare contact met de erven Harmsen van Beek, Joost Kircz en Geertje Zwaan, die er alles aan doen om de bronnen voor deze biografie voor mij te ontsluiten. Ik verheug mij in de medewerking van het Letterkundig Museum in Den Haag, directeur Aad Meinderts en hoofdconservator Salma Chen. Ik ben blij met maar liefst (hier ziet $U$ hoe we ze ondertekenden) twee nieuwe contracten met de Bezige Bij, een voor het schrijversprentenboek over Harmsen van Beek samen met Joost Kircz en een voor mijn biografie. Op deze foto ziet u ook Suzanne Holtzer en Henk Propper. Als moderne 65-plusser houd ik allerminst op met werken. De band met de Universiteit van Maastricht wordt wel losser en daarom sta ik hier. Ik dank deze universiteit voor mijn aanstelling als hoogleraar bij het Centrum voor Gender en Diversiteit waaraan ik samen met mijn voortreffelijke collega Mineke Bosch vorm mocht geven sinds 1998. Ik dank de Faculteit Cultuur- en Maatschappijwetenschappen - in de personen van Rein de Wilde en André Koehorst die ons sinds 2000 hebben gehuisvest en deel van de faculteit hebben gemaakt. Ik heb er fijne collega's ontmoet, zowel in de capgroep Letteren en Kunst als daarbuiten, ik heb er veel geleerd, en ik hoop en verwacht dat de faculteit zal mogen blijven genieten van de productiviteit en creativiteit van de leden van ons Centrum. Ik heb het grootste respect voor mijn geleerde collega Lies Wesseling die het Centrum alweer bijna twee jaar leidt als directeur en die nu Opzijhoogleraar is, de positie waarin ik zestien jaar geleden begon. Ik dank mijn directe collega's: naast Wesseling zijn dat nu Louis Van den Hengel, Agnes Andeweg, Ulrike Brunotte, Aagje Swinnen, Eliza Steinbock, en een hele groep geweldige PhD studenten -Van Eecke, De Bruijn, Verouden, Fronk en anderen met wie ik naar ik hoop nog lang contact zal blijven houden. Ik ben gehecht geraakt aan het Onderzoeksprogramma Arts, Media and Culture waaraan ik leiding mocht geven, aan de collega's met wie samen ik hier promoties heb begeleid en nog begeleid: Van de Vall, Verbeeck, Fickers, Vanhaesebrouck, Kusters, Labrie, Wenz, Peters en De Jong. Ik dank het University College Maastricht - in het bijzonder Louis Boon en Harm Hospers - dat ons de kans heeft gegeven sinds 2000 veel onderwijs op het gebied van gender en cultural studies te ontwikkelen. Ik heb me altijd in meerdere werelden bewogen - die van genderstudies in de eerste plaats, waar de samenwerking met Rosemarie Buikema en de haren uit Utrecht mij altijd een vreugde is geweest. Daarnaast zijn 
de neerlandistiek en de literatuurwetenschap me altijd blijven boeien, maar ook migratiestudies en de studie van populaire cultuuruitingen: het is fijn samen te werken met Peter Peters en Jac van de Boogard in een boek over populaire cultuur waarin Andre Rieu het uitgangspunt is. Ik verheug mij in interessante contacten met veel collega's in den lande die op alle bovengenoemde terreinen werkzaam zijn. Ik mag nog even aanblijven als honorair hoogleraar om mijn laatste zeven promovendi naar hun promotie te leiden - als dat lukt zal ik in mijn academische loopbaan 30 promovendi hebben afgerond, waarvan al tien voordat ik in Maastricht kwam. Ik ben blij met mijn carrière. Ik heb genoten van het onderwijs, ik geniet nog steeds van mijn promovendi, van werken, van jullie. Ik waardeer het enorm dat jullie, collega's uit andere steden, en natuurlijk ook de vriendinnen en vrienden en familie van mij en Veronie de lange reis naar Maastricht hebben ondernomen. Ik hoop dat ik nog diverse boeken en projecten kan afmaken en dat ze interessant zullen worden. Ik zeg bedankt! Mijn grootste dank gaat uit naar de vrouw van mijn hart, Veronie Koopmans, die mij zoveel jaren steunde en 'in de lucht hield' zoals zij dat zegt, of 'in het licht hield' zoals ik het nu zeg. Licht en lucht treden met jou elke dag weer mijn leven binnen lieve schat. Bedankt voor alles. En nu is het tijd voor een lekker slokje!

\section{Literatuur}

- Adkins, Lisa and Bev Skeggs (eds). Feminism After Bourdieu. Wiley/ Blackwell 2005 Alphen, Ernst van, Lizet Duyvendak, Maaike Meijer en Ben Peperkamp Op poëtische wijze. Bussum: Coutinho 1996 Andeweg, Agnes, 'Dit Is Echt Gebeurd,' in Vooys 16, 4: 50-51. Utrecht 1998

- Autofictie. Armada 16, 61, December 2010

- Balk-Smit Duyzentkunst, Frida, Fritzi en de sprookjes. Amsterdam: Thomas Rap 1996

- Barthes, Roland, Mythologies. Paris: Seuil 1957

- Boef, August Hans den en Joost Kircz (te verschijnen) 'F. Harmsen van Beek en de fritziana. De ontvangst van het literaire werk van F.H. ten Harmsen van der Beek, een casestudy.'

- Buikema, Rosemarie, 'Teveel werkelijkheid is dodelijk voor de kunst,' in: TNTL 126, 22010 202-216

- Buwalda, Peter, De wethouders van Juinen, Kellendonklezing 2013. Nijmegen: Radboud Universiteit 2013

- Dorleijn, Gilles, 'De auteur: levende dode en amfibie. Over de wisselende blik van de literatuurwetenschapper en zijn oogkleppen. In: Vooys 28, 2 (2010): 8-19

- Groot, Cornets de, 'Lichamelijke taal (Lucebert)', in: De open ruimte. Den Haag: Bert Bakker/Daamen 1967: 151-160

- Hanssen, Leon, 'Het kind vrijlaten,' 'in: Hanssen, Een misverstand om in te geloven. De poëzie van M. Vasalis. Amsterdam: Polak en Van Gennep 2007, p 168-177

- Hertmans, Stefan, Oorlog en Terpentijn. Amsterdam: De Bezige Bij, 2013

- Harmsen van der Beek, F. ten, Geachte Muizenpoot en achttien andere gedichten. Amsterdam: De Bezige Bij 1965

- Harmsen van der Beek, F. ten, Wat knaagt? Amsterdam: De Bezige Bij 1968

- Harmsen van der Beek, F. ten, Neerbraak. Amsterdam: De Bezige Bij 1968

- Harmsen van Beek, F., Gewone Piet en andere Piet. Amsterdam: Thomas Rap 1969

- Harmsen van Beek, F., (tekst) en Paul de Lussanet (tekeningen) Hoenderlust. Amsterdam: Erven Thomas Rap 1972

- Harmsen van Beek, F., Kus of ik Schrijf. Amsterdam: De Bezige Bij 1975

- Harmsen van Beek, F., In goed en kwaad. Verzameld werk. Amsterdam: De Bezige Bij 2012

- Hazeu, Wim, Gerrit Achterberg. Een biografie. Vierde uitgebreide druk, Amsterdam: De Arbeiderspers 200

- Hermsen, Joke, Kairos. Een nieuwe bevlogenheid. Utrecht: De Arbeiderspers 2014

- Hernnstein Smith, Barbara, Poetic Closure. A Study of How Poems End. Chicago/London Chicago University Press 1968

- Jansen, Suzanne, Het pauperparadijs. Een familiegeschiedenis. Amsterdam: Balans 2008

- Japin, Arthur, De zwarte met het witte hart. Roman. Amsterdam: De Arbeiderspers, 1997

- Johannes, Gert-Jan en Rudolf Dekker, 'Het egodocument: stiefkindje of oogappel?' in Vooys 17 Utrecht 1999: 22-29

- Kamphof, Ike, ledereen voyeur. Zoetermeer: Klement 2013 
- Kaplan, Cora, 'Examined Lives' [review van Miller (2002)] in: The Women's Review of Books 20, 2 (Nov. 2002): 11-12, 11

- Kermode, Frank, The Sense of an Ending. Studies in the Theory of Fiction. Oxford University Press 1967

- Koelewijn, Jannetje, 'lk houd mijn waarheid verborgen,'[interview met Stefan Hertmans] in: NRC Handelsblad 3 mei 2014, 14

- Lejeune, Philippe, Le Pact Autobiographique. Paris: Seuil 1975

- Lahire, B. La condition litteraire. La double vie des écrivains. Paris 2006

- Lee, Hermione, Virginia Woolf's Nose. Essays on Biography. Princeton: Princeton University Press 2005.

- Lorca, Federico Garcia. In Search of Duende. Prose selections, edited and translated by Christopher Maurer. London: New Directions 1998

- Meijer, Maaike, De lust tot lezen. Amsterdam:Van Gennep/Sara 1988

- Meijer, Maaike (ed), The Defiant Muse. Dutch and Flemish Feminist Poems from the Middle Ages to the Present. New York: The Feminist Press, 1998

- Meijer, Maaike, 'Hélène Swarth and the construction of masculinity in literary criticism, in: Rosemarie Buikema and Iris van der Tuin (eds) Doing Gender in Media, Art and Culture. London and New York: Routledge 2009. p. 223-237

- Meijer, Maaike, M. Vasalis. Een biografie. Amsterdam: Van Oorschot 2011

- Meijer, Maaike, 'Achterbergs autobiografie'. In: Tydskrif vir Nederlands en Afrikaans (TNA) 12, 2:184-205

- Meijer, Maaike, 'Hoor die muziek. Poëtica's van droefheid en troost,' in: Armada 12, 42 maart 2006: 70-81

- Miller, Nancy, But Enough About Me. Why We Read Other People's Lives, New York: Columbia University Press 2002

- Morris, Pam, Realism. London: Routledge 2003

- Nieuwenhuys, Rob, De dominee en zijn worgengel. Amsterdam: Van Oorschot 1964

- Otterspeer, Willem. De mislukkingskunstenaar. Willem Frederik Hermans. Biografie 1921-1952. Amsterdam: De Bezige Bij 2013

- Praat, Edwin, Verrek het is geen kunstenaar. Gerard Reve en het schrijverschap. Dissertatie. Amsterdam: UvA interne publicatie 2011

- Temme, Bart, 'Herinneringen als clusterbommen' [bespreking van Terrin, Post Mortem] in: Tzum literair weblog maandag 11 juni 2012

- Turkle, Sherry, Alone Together. New York: Basic Books 2011

- Withuis, Jolande, Juliana's vergeten oorlog. Amsterdam, De Bezige Bij 2014 [voorpublicatie van de Juliana-biografie]

- Zijl, Annejet van der, Jagtlust. Hoe in een Goois buitenhuis de wereld openging. Amsterdam: Meulenhoff 1998 
